\title{
Applications of sustainable biogas
}

\section{Zastosowanie biogazu spełniającego kryteria zrównoważonego rozwoju}

\author{
Delfina Rogowska, Michał Pajda \\ Oil and Gas Institute - National Research Institute
}

\begin{abstract}
In the article, a short review of possible biogas applications is presented. It is shown that biogas/biomethane can be used in many different ways. In particular, the following applications of biomethane are discussed: (1) as a transport fuel, (2) as a perspective heating fuel for the biofuel industry, (3) as feedstock to produce conventional motor fuels, and (4) as a valuable raw material for other branches of industry. For each use, the requirements and advantages of biogas/biomethane sustainability are discussed. In cases where biomethane is used as a transport fuel or as feedstock for the production of conventional motor fuels, meeting sustainability criteria and certification is legally required. In the other cases, a recipient's standards may be stricter than legal requirements in terms of sustainability, for example when biomethane is used as a heating fuel at a biofuel production plant in order to reduce greenhouse gas (GHG) emissions in the processing stage. Increasing the possibility of feeding biomethane into the natural gas grid would allow for the provision of bio-feedstock to other industries that use methane as a raw material, and would make the production of other goods more eco-friendly. In the article, different models of integrating biogas plants with the biofuel and fuel industries are presented. Due to the fact that sustainability aspects are vital from the certification point of view, these aspects are also discussed. In Poland, biogas plants currently operate mainly to produce electricity, but some entities deliver both heat and electricity (in the cogeneration case). In order to make biomethane a more common raw material or heating fuel, there is a need to feed it into the natural gas grid. This article briefly discusses the challenges that the biogas industry has to overcome in order to allow this material to become more widely used.
\end{abstract}

Key words: sustainability criteria, biogas, advanced transport biofuels.

STRESZCZENIE: W artykule przedstawiono krótki przegląd możliwych zastosowań biogazu. Pokazano, że biogaz/biometan może być wykorzystany na wiele różnych sposobów. W szczególności przedyskutowano następujące zastosowania: biometan jako paliwo transportowe, biometan jako perspektywiczne paliwo kotłowe w przemyśle biopaliwowym, biometan jako surowiec do produkcji konwencjonalnych paliw silnikowych, biometan jako wartościowy surowiec w innych gałęziach przemysłu. Dla każdej z wymienionych ścieżek przedyskutowano potrzeby i zalety udowodnienia spełnienia kryteriów zrównoważonego rozwoju. W przypadku wykorzystania biometanu jako paliwa transportowego lub jako surowca do produkcji konwencjonalnych paliw silnikowych prawnie wymagane jest spełnienie kryteriów zrównoważonego rozwoju i certyfikacja. W innych przypadkach oczekiwania odbiorcy w zakresie spełnienia kryteriów zrównoważonego rozwoju mogą być wyższe niż wymagania prawne, np. jeśli biometan jest wykorzystywany jako paliwo kotłowe w celu obniżenia emisji GHG dla procesu przetwarzania w zakładzie produkującym biopaliwo. Zwiększenie możliwości zatłaczania biometanu do sieci gazu ziemnego pozwala na zapewnienie biosurowca dla innych gałęzi przemysłu wykorzystujących metan i tym samym powoduje, że produkcja innych dóbr jest bardziej przyjazna dla środowiska. W artykule przedstawiono różne modele integracji biogazowni z przemysłem paliwowym i biopaliwowym. Aspekty związane z kryteriami zrównoważonego rozwoju są zasadnicze z punktu widzenia certyfikacji, dlatego również zostały przedyskutowane w artykule. Obecnie w Polsce zakłady produkujące biogaz pracują głównie na rzecz produkcji energii elektrycznej, ale niektóre podmioty dostarczają i ciepło, i energię elektryczną (w przypadku kogeneracji). Aby biometan stał się bardziej powszechnym surowcem lub paliwem kotłowym, konieczne jest wprowadzenie go do sieci gazu ziemnego. W artykule pokrótce wspomniano również o wyzwaniach, z którymi musi zmierzyć się przemysł biogazowy, aby ten produkt stał się szeroko wykorzystywany.

Słowa kluczowe: kryteria zrównoważonego rozwoju, biogaz, zaawansowane biopaliwa transportowe.

\section{Intoduction}

The obligation to use biofuels within the European Union dates back to 2003 (Directive 2003/30/EC); before this date, ethanol (which is produced from biomass) was a component of gasoline, added in order to complete the octane balance. Those years formed European society's traditional perception of renewable sources as a liquid biofuel in transport: FAME

Corresponding author: D. Rogowska, e-mail: delfina.rogowska@inig.pl

Article contributed to the Editor: 01.06.2020. Approved for publication: 24.09.2020 
(Fatty Acid Methyl Esters) and ethanol essentially obtained from agricultural raw materials. In the beginning, only quantity goals were set. However, there was a risk that increasing the minimum content of biofuel could cause an increased demand for agricultural raw materials, and thus the expansion of the cultivation of crops for biofuel purposes. In order to avoid the negative impacts of such an expansion, sustainability criteria were introduced by the RED Directive (Directive 2009/28/EC). The directive covers the time horizon through 2020. A continuation of the policy on renewable energy resources has been included in the new directive, RED II (Directive (EU) 2018/2001). This directive leaves space for biofuels produced from agricultural raw materials but limits their admissible percentage; at the same time, it promote biofuels produced from waste and residues.

It is important to note two passages from the RED II Directive. The first is Article 25, which lays out a sub-objective for fuels produced from raw materials specified in Annex IX, Part A of the directive (the so-called advanced feedstock). The second is Annex IX itself. In accordance with Article 25 (Directive (EU) 2018/2001), the share of biofuels produced from advanced feedstock is to gradually increase to reach a minimum of $3.5 \%$ by 2030 (the so-called advanced biofuel target). Annex IX lists the waste-based feedstock that can be used to produce biofuels to achieve this objective.

As a result of the RED/RED II provisions, biofuels made from waste-based raw materials are to be used in transport. The main challenge for the fuel sector is to provide conventional fuels (diesel, gasoline) containing biofuels that are produced from advanced raw materials, or, in other cases, the challenge is to find alternative fuels for alternative motors that are still produced from this advanced feedstock. It should be noted that the current road transport is carried out with the use of cars equipped with internal combustion engines. The structure of the car fleet in Poland is presented in Table 1.

Table 1. Structure of the car fleet in Poland [data source: Polski Związek Przemysłu Motoryzacyjnego, 2015]

Tabela 1. Struktura parku samochodowego w Polsce [źródło: Polski Związek Przemysłu Motoryzacyjnego, 2015]

\begin{tabular}{|c|c|c|}
\hline $\begin{array}{c}\text { Type of fuels used } \\
\text { in cars }\end{array}$ & No. of items & $\begin{array}{c}\text { \% share of the car fleet } \\
{[\%]}\end{array}$ \\
\hline \hline Petrol & $6,852,029$ & 45.04 \\
\hline Diesel & $5,706,252$ & 37.51 \\
\hline LPG & $2,461,166$ & 16.18 \\
\hline CNG & 2,746 & 0.02 \\
\hline Electric & 703 & 0.00 \\
\hline Hybrid & 17,281 & 0.11 \\
\hline Others & 171,391 & 1.13 \\
\hline
\end{tabular}

If the structure of the car fleet and the global transportation model (which currently relies heavily on road travel) does not transform within ten years to use only alternative-fuel vehicles, the challenge for the fuel industry in 2030 will be to meet the $3.5 \%$ target of biofuels produced from the raw materials listed in Annex IX to RED II. Furthermore, biofuels are now required to meet the GHG emission reduction targets, and this requirement is maintained and extended in the RED II Directive:

- $50 \%$ for biofuels, biogas used in transport, and bioliquids produced in systems in operation before October 5, 2015; - $60 \%$ for biofuels, biogas used in transport, and bioliquids produced in systems started after October 5, 2015;

- $65 \%$ for biofuels, biogas used in transport, and bioliquids produced in systems which will be started after January 1, 2021.

The challenge for the fuel and biofuel industry will be the production of biofuel that can be used in the Polish fleet of vehicles and that meets the objective to reduce greenhouse gas (GHG) emissions. A solution to this problem may be the extensive use of biogas in the biofuel industry.

After treatment (to improve biomethane quality) and compression, biogas can be fed into the natural gas network. This action may allow biogas plants to diversify their recipients, and it may also create the possibility of increasing the use of renewable raw materials within society at large. Biomethane from the natural gas network can be used for energy purposes, chemical syntheses, and the production of engine fuels in refineries. As was shown by Rogowska (2018), biogas (biogas plants) can significantly help in the introduction of the circular economy. Regardless of the destination of the biomethane/ biogas, it is crucial that this fuel meets sustainability criteria. As was shown in (Longa and Murphya, 2019), certification requirements may affect the biogas industry.

\section{Biomethane as motor fuel}

The first and main application of biogas (biomethane) in the transport sector is its use as a component of compressed natural gas (CNG). This fuel has been widely used globally for many years (Rogowska and Kaczmarczyk, 2004). In countries where CNG is used, significant fleets of CNG cars have followed, mainly in the form of heavy-duty cars. In this case, using biomethane instead of natural gas is the easiest way to increase the share of renewable energy in the transport sector. This has been seen not only in the European Union, but also in many Asian counties (Goulding et al., 2019); furthermore, in California, several policies are in place to facilitate the development of biomethane (Von Wald et al., 2019). According to (Gil-Carrera et al., 2019), biomethane as a vehicle fuel is greatly 
preferable for generating power without external heat recovery, and biomethane delivers greater environmental benefits than both biodiesel and first-generation bioethanol. This is why biomtehane industry is strongly developing in Europe. Among European countries Italy has the highest number of $\mathrm{CNG}$ refuelling stations (after Germany), (Gil-Carrera et al., 2019).

For heavy-duty vehicles, a more appropriate form of (bio) methane is liquefied natural gas (LNG). However, in all cases, if bio-origin fuel is used for transport, it is always required to meet sustainability criteria; otherwise, not only would legal requirements not be met, but it would be more harmful for the environment than fossil fuels. Thus it is important to provide GHG emission values for the entire life cycle of bio-origin fuels. These calculations should be carried out according to the methodology outlined in a certification scheme, e.g. KZR INiG (KZR INiG). Otherwise, biogas cannot be included in the national biofuel quota. What is more, calculations and proof of meeting other sustainability criteria should be verified during an audit before a certificate can be issued. Meeting GHG emission requirements is a indispensable component of receiving a certificate. GHG emission values can be presented as an actual or default value. Actual value is calculated based on the actual use of media and raw materials, while default value is taken from the directive. If biomethane/biogas is to be used as a motor fuel, it can achieve up to $65 \% \mathrm{GHG}$ reduction in relation to fossil fuels (depending on the date of the installation start-up).

\section{Biomethane as a perspective heating fuel for the biofuel industry}

Biofuels have to meet sustainability criteria, including those related to the reduction in GHG emissions over its life cycle. Energy media used in a production plant account for a significant part of such emissions. When using natural gas in a boiler for the production of energy in the form of steam, the GHG emission factor for this energy resource is $66.20 \mathrm{gCO}_{2} / \mathrm{MJ}$ for natural gas imported from Russia (EC Europa). Enabling the introduction of biomethane instead of fossil gas would cause this emission factor, depending on the biomethane production procedure, to potentially reach the level of $35 \mathrm{gCO}_{2} / \mathrm{MJ}$ (the biogas production procedure from maize with closed digestate and waste gas after-burning (Biograce)), i.e. nearly half that of the fossil fuel. In order to illustrate the significance of this GHG emission component, the GHG emission of ethanol from wheat was recalculated using the Biograce calculator (Biograce). Assuming that GHG emission factor for heating fuels was only variable, Results are shown in Table 2. Details regarding how to calculate GHG emission and savings are described in the document entitled "System KZR INiG/8" (KZR INiG).
Table 2. GHG emission in ethanol life cycle depending on the heating gas emission factor

Tabela 2. Emisja GHG w cyklu życia etanolu w zależności od wskaźnika emisji gazu opałowego

\begin{tabular}{|c|c|c|}
\hline $\begin{array}{c}\text { GHG emission factor } \\
\text { for heating gas }\end{array}$ & $\begin{array}{c}\text { GHG emission in } \\
\text { ethanol life cycle }\end{array}$ & Saving \\
\hline [gCO $_{\text {2eq }}$ /MJ] & [gCO $_{\text {2eq }}$ /MJ] & {$[\%]$} \\
\hline 66.2 & 54.6 & 35 \\
\hline 35.0 & 45.2 & 46 \\
\hline 26.1 & 42.2 & 50 \\
\hline
\end{tabular}

In the basic variant, in which the fossil natural gas factor (66.2 $\left.\mathrm{gCO}_{2 \mathrm{eq}} \mathrm{MJ}\right)$ is used to calculate the GHG emissions, the total GHG emission in the life cycle (i.e. the value including all stages starting from wheat cultivation) is $54.6 \mathrm{gCO}_{2} / \mathrm{MJ}$ for bioethanol, which translates to a $35 \%$ reduction in $\mathrm{GHG}$ emissions relative to the fossil equivalent. The minimum threshold currently required is $50 \%$ for systems in operation before October 5, 2015, and 60\% for newer installations. GHG emission factor for heating gas falls to $26.1 \mathrm{gCO}_{2 \mathrm{eq}} / \mathrm{MJ}$ for biomethane produced from manure where there is no combustion of off gases and digestate is stored in an open container. Changing, only at the distillery stage, the boiler fuel from natural gas to biomethane with an emission factor of $26.1 \mathrm{gCO}_{2} / \mathrm{MJ}$, a life-cycle $\mathrm{GHG}$ emission of $42.2 \mathrm{gCO}_{2} / \mathrm{MJ}$ is achieved, which translates to a 50\% reduction in $\mathrm{GHG}$ emissions. Thus, it is possible to meet the GHG threshold using the same crops as feedstock.

In the above scenario, the main challenge is the purchase of biomethane. The easiest way to do that is if a biogas plant is integrated with a distillery. This scheme is presented in Figure 1.

In such a system, the distillery is closely integrated with the biogas plant, and the raw material for the biogas plant is the stillage obtained from the distillery; this material can also be supplemented with other raw materials. The biogas produced is burnt in a cogeneration unit, and the heat generated in the form of steam is used in the distillery for the production process. Such a system functions well and is complementary to the production of bioethanol. System boundaries cover all above-mentioned installations. Inputs are feedstock for distillery, chemicals, and other auxiliaries, and outputs are ethanol (biofuel), a surplus of electricity transferred to grid, and digestate (to be used as fertilizer).

In the production of biodiesel, no residues or other streams are created that could be suitable for methane fermentation from a technological/economic point of view. Therefore, in other cases, in order to be able to use biomethane for heating purposes, the flowchart shown in Figure 1 would have to be modified to make it possible to purchase biomethane from any plant producing biofuels, using the natural gas network (Fig. 2). 


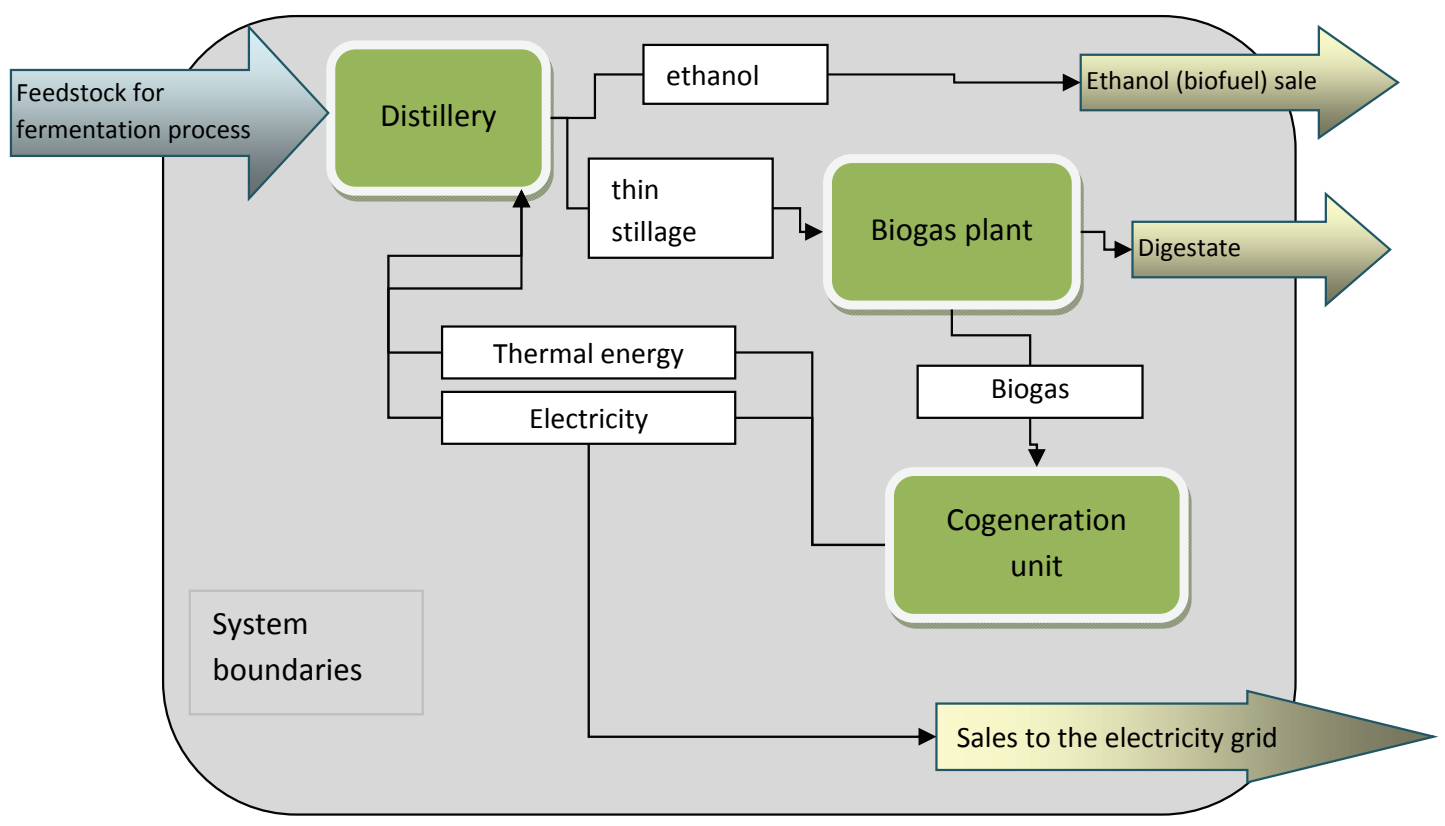

Fig. 1. Diagram of biogas utilisation in a distillery integrated with a biogas plant

Rys. 1. Schemat wykorzystania biogazu w gorzelni zintegrowanej z biogazownią

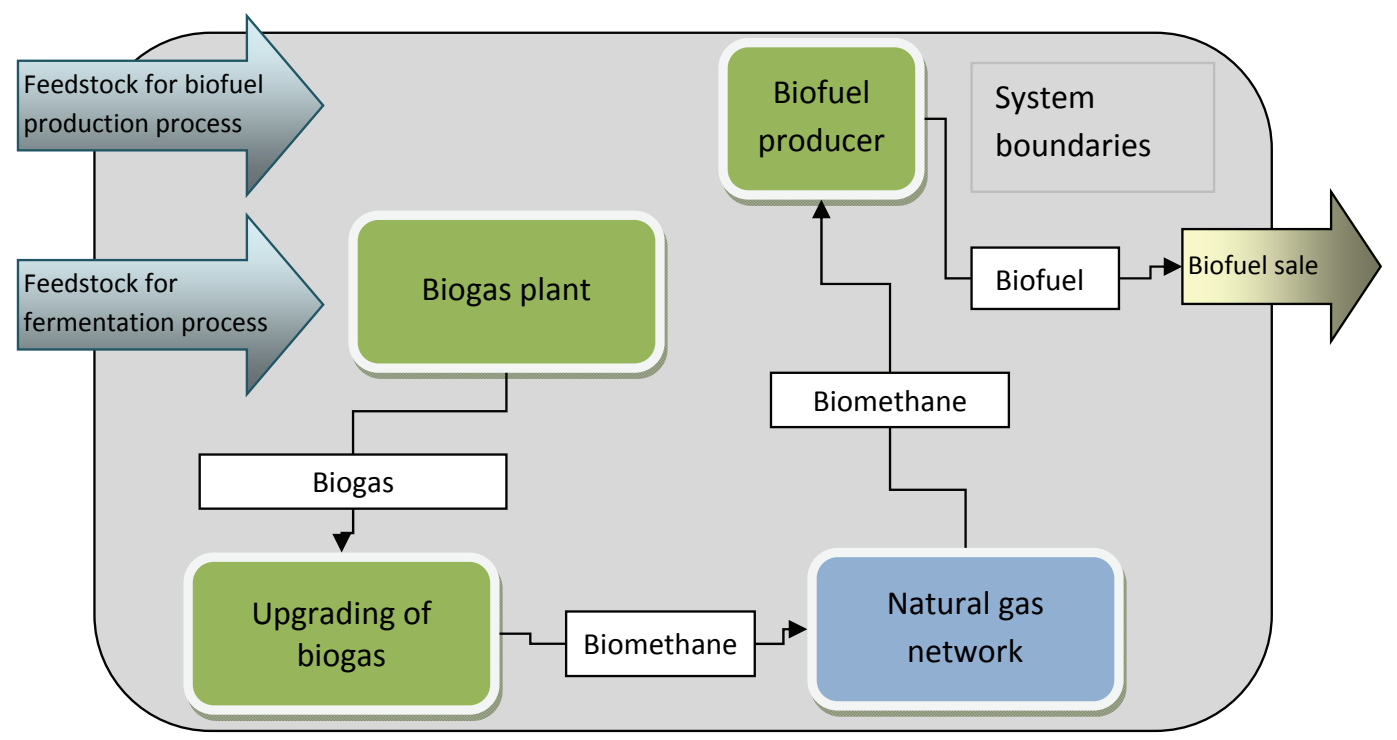

Fig. 2. Diagram of biogas utilisation in the production of biofuels through the natural gas network

Rys. 2. Schemat wykorzystania biogazu, poprzez sieć gazu ziemnego, w produkcji biopaliw

In the above system, the biogas plant produces biogas from any raw material, which is then upgraded to achieve the quality of natural gas (biomethane) and fed into the network (Piskowska-Wasiak, 2014). Through the natural gas network, it reaches the recipient, the biofuel producer, where it is burnt in a boiler to generate the energy needed in the production process. Such a solution enables the application of the GHG emission factor for biomethane in the calculations of GHG emissions in the biofuel life cycle. This GHG emission factor should be calculated according to the RED (RED II) methodology. Such an approach can be applied not only to a distillery integrated with a biogas plant, but to every production plant in the supply chain of biofuels where natural gas is burnt in a boiler. In this case, the system boundaries cover: the biogas plant, the upgrading unit, the natural gas network, and the biofuel producer. What is more, biomethane can be used as a complement to natural gas according to this model (Piskowska-Wasiak, 2018).

\section{Biomethane as feedstock to produce conventional motor fuels}

In some cases, biomethane can be a component of conventional engine fuels. In a refinery, when crude oil is processed for the production of engine fuel components, hydrogen is used. In hydrogen-based processes such as hydrodesulfurisation, this hy- 


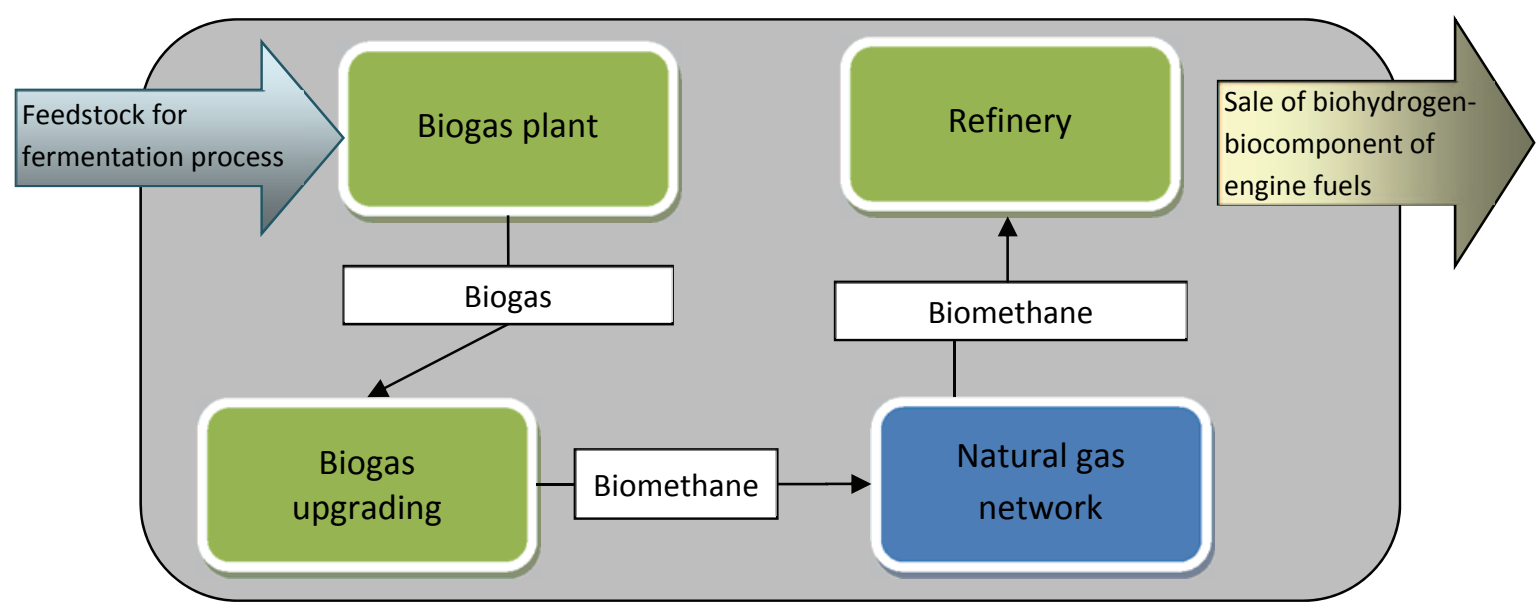

Fig. 3. Diagram of biomethane utilisation in a refinery

Rys. 3. Schemat wykorzystania biogazu w rafinerii

drogen is incorporated into a hydrocarbon molecule. Hydrogen is very often produced from methane during the process of steam reforming. The use of biomethane in a refinery, in place of methane from fossil sources, would enable the production of biohydrogen; this would then become a component of hydrocarbon engine fuels (Aptowicz, 2017), making the biofuel a part of conventional fuel. In this case, the flowchart from Figure 2 would take the form presented in Figure 3.

In such a system, the biogas plant is not limited to using a single raw material. Depending on local conditions, it may use a mixture of various raw materials, including waste fractions and manure, i.e. the raw materials listed in Annex IX of the ILUC Directive/RED II (Directive (EU) 2015/1513). Biomethane produced from these raw materials may be eligible for double counting against the energy value of the biofuel (biohydrogen being a part of conventional fuel). In view of the growing share of biofuels produced from raw materials, as listed in Annex IX, the use of biomethane for the production of biohydrogen, which then becomes a biocomponent in refinery processes, poses a considerable opportunity for the fuel industry to meet that objective. However, the use of biomethane in the production of biohydrogen, a component of conventional hydrocarbon fuels, is not within the current legal framework defining the operating principles of the biofuel market. This possibility creates a new market for biomethane, making the biogas business more flexible and resistant to the challenges of the power market.

\section{Biomethane, a valuable raw material}

Methane is not only a fuel. It is also a valuable raw material for syntheses and other chemical processes. Biomethane distribution through the natural gas network can, therefore, contribute to an increase in the use of bio-based raw materials in the chemical industry. Increasing society's awareness of the need to use natural resources and to reduce waste may prompt a consumer to buy goods produced in such a way, even if such a good were more expensive. No legal requirements have been implemented for such a case, but the recipient of biomethane should be aware of sustainability criteria and should choose raw materials that can be reliably shown to meet sustainability criteria, including, in particular, criteria concerning GHG emission savings.

\section{Sustainability of biomethane}

In the natural gas network, biomethane particles form a homogeneous mixture with fossil-derived methane. It is not possible to physically track molecules of biological origin and supply them to a specific recipient through the natural gas network. Voluntary schemes do not require the physical tracking of molecules or the physical segregation of sustainable batches of products from nonsustainable batches. Supervision of sustainability characteristics and volumes of batches is carried out based on documents such as invoices and documents of receipt. However, it is necessary to introduce a system for monitoring the biomethane balance in the natural gas network; this system would, among others, prevent a biogas plant from, mistakenly or deliberately, issuing proofs of sustainability (POSs) in excess of the biomethane fed into the network, or issuing POSs that provide incorrect information about GHG emissions. In the case of conventional biofuels, this is the role of certification systems recognised by the European Commission. The same rules should be applied to biomethane fed into the natural gas network.

It is important to create an appropriate mass balance system in an enterprise to oversee the inputs and outputs to/from the plant and manage streams in such a manner that the sustainability characteristics are assigned to each batch to ensure traceability. The implementation of a certification system such as the KZR INiG (KZR INiG) would allow for the monitoring 
of batches of biomethane injected into the network, particularly in terms of quantity. The certification system would not only enable the supervision of the amount of biomethane injected into the network, received by a refinery, or received by a biofuel manufacturer, but also ensure that biomethane meets sustainability criteria and provide reliable GHG emission factors used for further calculations by the recipient.

In Figure 3, biohydrogen produced from biomethane becomes a biocomponent of engine fuels. In accordance with the RED and RED II Directives, each biofuel has to meet the sustainability criteria. The criteria can be divided into two groups, namely those related to land and those related to the reduction of GHG emissions. Meeting these criteria is subject to certification, e.g. via the KZR INiG System (KZR INiG).

If the biomethane is produced from agricultural raw materials (e.g. maize), it will be necessary to verify the land on which they have been grown. However, land criteria are not applicable to waste and residues other than those from agriculture.

The second group of criteria involves the reduction of GHG emissions. The RED and RED II Directives set out different minimum thresholds for GHG emission savings depending on the type of fuel (biofuel, biomass fuel, bioliqiud) and the start date of the installation. Biomethane plants are obliged to meet this threshold. If biomethane is not a final fuel, but it is a feedstock for further processing in order to receive biofuel as described above, the biomethane plant does not calculate GHG emission savings. It is due to the fact that additional emissions generated at the refinery stage are to be added and finally the refinery calculates the GHG emission savings (Berdechowski, 2019).
The RED II Directive clearly separates GHG emission saving requirements for biomethane for energy purposes from biomethane for transport purposes, and it provides many more default values for different production pathways than RED I. In Table 3, the default GHG emission savings for biogas used in transport are quoted from the RED II Directive.

Data presented in Table 3 indicate that maize, due to GHG emission, is not a prospective raw material for the production of biomethane. What is more, crop-based fuels are produced from maize and thus are not double-counted biofuels according to RED/RED II Directives. The technology of the fermentation process, the encapsulation of digestate, and the after-burning of off-gases is of great importance. For biomethane production from bio-waste, the closure of digestate and the after-burning of waste gases result in a reduction in emissions between $20 \%$ and $80 \%$. Thus, only modern, fully hermetic biogas plants will be able to function in this market; otherwise, the use of raw materials listed in Annex IX (e.g. biowaste) may not be sufficient to meet the sustainability criteria.

The provided values only apply to biomethane used in transport. If biomethane is used as a raw material for further processing, e.g. for the production of biohydrogen as a biocomponent of engine fuels, then the values from Table 3 cannot be used. The biogas plant would be required to determine the actual GHG emissions for the fermentation and biogas upgrading. Furthermore, it would be necessary to add the emissions generated at further steps (the refinery) to the GHG emission of the methane generated during the fermentation stage, and to determine the emission savings not for biomethane but for the final biofuel.

Table 3. GHG emission savings for biogas used in transport, according to the RED II Directive

Tabela 3. Redukcja emisji GHG biogazu wykorzystywanego w transporcie, według dyrektywy RED II

\begin{tabular}{|c|c|c|c|}
\hline \multicolumn{4}{|c|}{ BIOGAS FOR TRANSPORT ${ }^{*}$} \\
\hline \multirow{2}{*}{ Biogas production system } & \multirow{2}{*}{ Technological option } & $\begin{array}{l}\text { Greenhouse gas emissions } \\
\text { savings - typical value }\end{array}$ & $\begin{array}{l}\text { Greenhouse gas emissions } \\
\text { savings - default value }\end{array}$ \\
\hline & & {$[\%]$} & {$[\%]$} \\
\hline \multirow{4}{*}{ Wet manure } & Open digestate, no off-gas combustion & 117 & 72 \\
\hline & Open digestate, off-gas combustion & 133 & 94 \\
\hline & Close digestate, no off-gas combustion & 190 & 179 \\
\hline & Close digestate, off-gas combustion & 206 & 202 \\
\hline \multirow{4}{*}{ Maize, whole plant $\left({ }^{4}\right)$} & Open digestate, no off-gas combustion & 35 & 17 \\
\hline & Open digestate, off-gas combustion & 51 & 39 \\
\hline & Close digestate, no off-gas combustion & 52 & 41 \\
\hline & Close digestate, off-gas combustion & 68 & 63 \\
\hline \multirow{4}{*}{ Biowaste } & Open digestate, no off-gas combustion & 43 & 20 \\
\hline & Open digestate, off-gas combustion & 59 & 42 \\
\hline & Close digestate, no off-gas combustion & 70 & 58 \\
\hline & Close digestate, off-gas combustion & 86 & 80 \\
\hline
\end{tabular}

* GHG emissions savings for biomethane only refer to compressed biomethane relative to the fossil fuel comparator for transport of $94 \mathrm{~g} \mathrm{gCO} 2 \mathrm{eq} / \mathrm{MJ}$. 


\section{Challenges faced by biomethane producers}

Biogas/biomethane is perceived as a very promising fuel. The methane fermentation process, in which the fuels are generated, allows for the management of waste and its sustainable disposal, during which additional sources of energy are obtained. Developing the market for biogas plants in Poland will make it possible to reduce the reliance on natural gas supplies and provide a tool to increase the share of renewable energy. Moreover, the use of biogas can play a significant role in the biofuel industry.

In order for the biomethane to be received by entrepreneurs in Poland, it is necessary to inject it into the natural gas network. Such activities are not currently widespread and developing an appropriate procedure at the administrative level would significantly facilitate the growth of this industry. Creating opportunities to supply biomethane to recipients in the biofuel/transport fuel industry will allow for the diversification of recipients of this energy medium, which will increase the competitiveness of this market and stimulate its further development. Moreover, this solution may help in reducing organic waste storage, as the waste would otherwise go to landfill and/or generate high levels of fugitive methane emission; it is also in line with goal of a circular economy (Rogowska, 2018). However, without the development of the biomethane market, meeting the RES (renewable energy sources) objectives in transport, in particular those regarding the share of biofuels made from the raw materials listed in Annex IX of the directive, will be difficult or even impossible. There are significant challenges, in addition to legislation, including the high costs of biomethane production. According to (Gil-Carrera, et al., 2019), a minimum revenue of $€ 1.10$ per $\mathrm{Nm}^{-3}$ of biomethane is required for financial sustainability.

Importantly, for biomethane to be acceptable for a recipient operating in the fuel and biofuel industries, it will be necessary to certify compliance with the sustainability criteria, including the calculation of the GHG emission factor and mass balance management in accordance with the rules of a certification system, e.g. the KZR INiG.

\section{Literature}

Aptowicz D., 2017. BIOH2 - paliwo alternatywne przyszłości. The $8^{\text {th }}$ edition of the FUELS 'ZOOM 2017 Scientific and Technical Conference entitled "Biofuels and other alternative fuels and the future of liquid fuels", Krakow.

Berdechowski K., 2019. Analiza metod produkcji biowodoru pod kątem wielkości emisji GHG. Nafta-Gaz, 4: 230-235. DOI: 10.18668/NG.2019.04.05.

Biograce; https://www.biograce.net/ (access: May 2020).

EC Europa. https://ec.europa.eu/energy/en/topics/renewable-energy/ biofuels/voluntary-schemes. (access: July 2019).
Gil-Carrera L., Browne J.D., Kilgallon I., Murphy J.D., 2019. Feasibility study of an off-grid biomethane mobile solution for agri-waste. Applied Energy, 239: 471-481.

Goulding D., Fitzpatrick D., O'Connor R. Browne J.D., Power N.M., 2019. Introducing gaseous transport fuel to Ireland: A strategic infrastructure framework. Renewable Energy, 136: 548-557.

KZR INiG. www.kzr.inig.eu (access: May 2020).

Longa A., Murphya J.D., 2019. Can green gas certificates allow for the accurate quantification of the energy supply and sustainability of biomethane from a range of sources for renewable heat and or transport? Renewable and Sustainable Energy Reviews, 115: 109347.

Piskowska-Wasiak J., 2014. Uzdatnianie biogazu do parametrów gazu wysokometanowego. Nafta-Gaz, 2: 94-105.

Piskowska-Wasiak J., 2018. Możliwości komplementarnego wykorzystania gazu ziemnego i odnawialnych źródeł energii. Nafta-Gaz, 4: 290-297. DOI: 10.18668/NG.2018.04.05.

Polski Związek Przemysłu Motoryzacyjnego https://www.pzpm.org.pl/ Rogowska D., 2018. Produkcja biopaliw jako element gospodarki o obiegu zamkniętym. Nafta-Gaz, 2: 156-163. DOI: 10.18668/ NG.2018.02.10.

Rogowska D., Kaczmarczyk A., 2004. Sprężony gaz ziemny jako paliwo alternatywne. Biuletyn ITN, 2: 122-136.

Von Wald G.A., Stanion A.J., Rajagopal D., Brandt A.R., 2019. Biomethane addition to California transmission pipelines: Regional simulation of the impact of regulations. Applied Energy, 250: 292-301.

\section{Legal acts and standards}

Directive (EU) 2015/1513 of the European Parliament and of the Council of 9 September 2015 amending Directive 98/70/EC relating to the quality of petrol and diesel fuels and amending Directive 2009/28/EC on the promotion of the use of energy from renewable sources (Journal of the European Union L 239/1.).

Directive (EU) 2018/2001 of the European Parliament and of the Council of 11 December 2018 on the promotion of the use of energy from renewable sources (Official Journal of the European Union L 328/82.).

Directive 2003/30/EC of the European Parliament and of the Council of 8 May 2003 on the promotion of the use of biofuels or other renewable fuels for transport (OJ L 123, 17.5.2003, p. 42).

Directive 2009/28/EC of the European Parliament and of the Council of 23 April 2009 on the promotion of the use of energy from renewable sources and amending and subsequently repealing Directives 2001/77/EC and 2003/30/EC (Official Journal of the European Union L 140/16.).

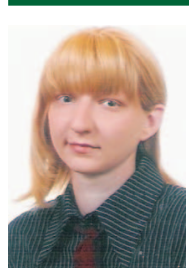

Delfina ROGOWSKA M.Sc. Eng.

Manager of of the Biomass Certification Systems Office, Senior Research and Technical Specialist at the Department of Fuel and Catalytic Processes Oil and Gas Institute - National Research Institute 25 A Lubicz St., 31-503 Krakow E-mail:delfina.rogowska@inig.pl

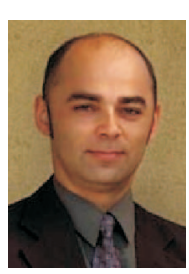

Michał PAJDA Ph.D. Eng

Assistant at the Department of Fuel and Catalytic Processes, KZR INiG System auditor Oil and Gas Institute - National Research Institute 25 A Lubicz St.

31-503 Krakow

E-mail:michal.pajda@inig.pl 